\title{
AUGUSTUS AND DIONYSUS'S TRIUMPH: A NONEXISTENT PARADOX
}

\begin{abstract}
Summary: In this paper I shall describe several iconographic documents attesting the resounding success of a few Dionysiac themes and, more generally, the vitality of Dionysism in the Augustan Age. These materials confirm that in the years of the triumph of Augustus no dichotomy between Dionysus and Apollo was perceived. Amidst the late civil war of the Roman Republic what was fearful was Antony regardless of his identification to Dionysus. Indeed, Dionysus, as Liber, civilizing god, benefactor of Mankind and winner of every enemy and threat, represented an ideal model for young Octavianus, in the same way as Romulus, Hercules and the Dioscouri had proven. In particular, the iconographies highlight that even the particular Dionysiac cult practised by Antony, influenced as it was by Hellenistic beliefs, continued to enjoy great status during the years of the new Augustan era. Indeed, in the first years of his government Augustus might well have taken advantage of the semantic of the Hellenistic royalty, implied by the symbolism inherent within the Alexandrine Dionysus triumphant.
\end{abstract}

Key words: Augustan political propaganda, Dionysus, Dionysiac triumph, Hellenistic interpretation of royalty, private iconography, Augustan coins, Ara Pacis, Casa della Farnesina

\section{INTRODUCTION}

In the following pages I intend to single out a few themes concerning Dionysus within Augustan art and literature. Indeed, while there are countless studies concerning Augustus, his age and policy and a huge bibliography on Dionysus covering diverse periods and contexts of the Roman epoch, little discussion has actually taken place, thus far, as regards Dionysiac themes specifically within the Augustan Age. In other words, the binomial Augustus-Dionysus has barely been able to arouse interest among scholars. While this fact may, of course, be purely accidental, nevertheless I believe there exists a precise reason that has discouraged such a research perspective, which I will now elucidate below. 


\section{Status quaestionis}

The scholarly debate on Dionysus and Octavian has essentially focused its attention on the years before the battle of Actium. From the works published in the 20's and 30's by Jeanmaire and Kenneth Scott onwards, numerous studies have been dedicated to Antony's identification with Dionysus, consistent with the Hellenistic Dionysiac interpretation of royalty, the consequent censure and mockery by Octavian as well as Antony's reply, evoked in the Antonian pamphlet De sua ebrietate. ${ }^{1}$ Augustus's rather distinctive worship of Apollo, the patron of the victory at Actium, has also received considerable critical attention. The impact of these propagandistic trends and of Augustus's interest in Apollo on the pre- and post-Actium iconography have been analysed by Paul Zanker in his well known work Augustus und die Macht der Bilder, published in $1987,{ }^{2}$ which underscores the spreading of Apollonian themes and motifs within Augustus's visual imagery.

I am convinced that it is precisely this identification with Dionysus by the great political adversary of Octavian that has in part affected the scholarly interpretation of Dionysus within the Augustan epoch. That is to say, in view of the fact that in the years preceding the battle of Actium Octavian's adversary identified himself with Dionysus, Octavian could not have but a bad opinion of Dionysus. As a result, the opposition between Octavian and Antony is thus automatically ascribed to the couple Octavian-Dionysus.

Moreover, this somewhat automatic interpretation has been undoubtedly influenced by - and is to a certain extent mingled with - the renewed conception of "Apollonian versus Dionysian" proposed by Nietzsche. ${ }^{3}$ Its echo together with certain attributes of Apollo and Dionysus that appeared, to some extent, as complementary, ${ }^{4}$ might well have led to the interpretation of the political contrast between Antony and Octavian in light of a presumed inherent contrast between two gods, religions and moral principles.

${ }^{1}$ JeAnMaire, H.: La Politique religieuse d'Antoine et de Cleopatre. RevArch 19 (1924) 258-259; SCOTT, K.: Octavian's Propaganda and Antony's De Sua Ebrietate. Classical Philology 24 (1929) 133141; ScotT, K.: Political Propaganda of 40-30 BC. Memoirs of the American Academy in Rome 11 (1933) 7-49. Also Rossi, R. F.: Marco Antonio nella lotta politica della tarda Repubblica romana. Trieste 1959, 143-169. See the recent MARASCO, G.: Marco Antonio «Nuovo Dioniso» e il De sua ebrietate. Latomus 51 (1992) 538-548. See also BRENK, F. J.: Antony-Osiris, Cleopatra-Isis: The End of Plutarch's Antony. In Stadter, PH. A. (ed.): Plutarch and the Historical Tradition. London - New York 1992, $159-182$.

${ }^{2}$ ZANKeR, P.: Augustus und die Macht der Bilder. München 1987. I will quote the English version of this book: The Power of Images in the Age of Augustus. Trans. by A. Shapiro. Ann Arbor 1990.

${ }^{3}$ This is, for instance, the idea of Kellum, B. A.: What We See and What We Don't See. Narrative Structure and the Ara Pacis Augustae. Art History 17.1 (1994) 26-45, esp. 41, n. 14 (quoted by SAURON, G.: L'histoire végétalisée. Ornament et politique à Rome. Paris 2000, 51) and of GALINSKY, K.: Continuity and Change: Religion in the Augustan Semi-Century. In RÜPKE, J. (ed.): A Companion to Roman Religion. Malden Ma. 2007, 76. Regarding the limits of Nietzsche's interpretation, see DETIENNE, M.: Forgetting Delphi between Apollo and Dionysus. Classical Philology 96.2 (2001) 147-158.

${ }^{4}$ See, for instance, GRAF, F.: Apollo. London - New York 2009, 169-171. 
The idea of a virtual ontological opposition between an "Apollonian" and a "Dionysian" way of life has been claimed, for instance, by Zanker, who concentrated on the Augustan iconography: "In the early years of charge and countercharge, the beginnings of a notion of cultural dichotomy between Apollonian and Dionysian had emerged. Classicism and archaism became after Actium the vehicle of 'Apollonian culture', an outward symbol of moral revival. The purely formal - i.e., style - became the meaning." In the second chapter of his book, "Rival Images: Octavian, Antony and the Struggle for Sole Power", Zanker consistently expresses his theory of an "iconomachy" between Octavian and Antony based precisely on the respective identification with Dionysus and with Apollo.

The idea of an ontological polarity between Apollo and Dionysus and the assumption that, since Antony had Dionysus as a model, Octavian must have discredited this god, gained further support in the 1970's, following the publication of Mannsperger's Apollon gegen Dionysos. ${ }^{6}$ Therein, Mannsperger supposes that the reason behind the supplanting of olive with laurel as an attribute of Pax on coins struck by Octavian in the East in $28 \mathrm{BC}$, was to contrast the ivy crown of Dionysus. Indeed, the formula Apollon gegen Dionysos clearly promotes the idea of an inherent antagonism between the two gods and of a consequential problematic relationship of Octavian, great worshipper of Apollo, with Dionysus and the Dionysiac values. Mannsperger speaks of "Dionysiac Hellenistic anti-Roman tendencies" which he presumes threatened the Romans on different occasions, ${ }^{7}$ arguing that this phenomenon reached its apex with this rivalry between Octavian and Antony: Octavian would inevitably oppose the cult of Apollo against Antony-Neos Dionysus. ${ }^{8}$

We also find an echo of these ideas in more recent works. For instance, in his analysis of the contrast between Antony and Octavian, Joseph Reed in his work The Death of Osiris in Aeneid 12. 458, speaks of "a long-standing suspicion and fear of Bacchic mystery cults as dangerous and un-Roman, not to mention the drunken debauchery implied by the Bacchic model, against which Octavian could cultivate an image of Apollonian - and eminently Roman - sobriety".9

\footnotetext{
${ }^{5}$ ZANKER (n. 2) 240.

${ }^{6}$ MANNSPERgER, D.: Apollon gegen Dionysos. Numismatische Beitrage zu Octavians Rolle als Vindex Libertatis. Gymnasium 80 (1973) 381-404.

${ }^{7}$ In $213 / 2$, in the years before the senatus consultum of $186 \mathrm{BC}$ regarding the Bacchanalia, during the Social War and during the wars against Mithridates Neos Dionysus: MANNSPERGER (n. 6) esp. 389-394.

${ }^{8}$ MANNSPERGER (n. 6) 394.

${ }^{9}$ REED, J. D.: The Death of Osiris in "Aeneid" 12.458. The American Journal of Philology 119 (1998) 399-418, here 405. See also Marie-Laure Freyburger who, analysing the propaganda pre-Actium, defines Dionysus as "Apollo's great rival" and claims the existence in that circumstance of a real "dispute" between the two gods (FreYburger, M.-L.: Political and Religious Propaganda between 44 and 27 BC. Vergilius 55 [2009] 17-30, and esp. 24-27): "The opposition between the two gods corresponds to two operating ways of life embodied by each of the two ideologies and to the different chiefs: order and disorder, West and East, tradition and innovation, austerity and pleasure. In fact, it is in playing on these distinctions that the propaganda and contra-propaganda unfold, and it has to be appreciated that this Dionysiac theme made it possible to publish pamphlets and invectives which in fact had nothing whatever to do with theology or philosophy" (p. 25). See also the recent MiLler, J. F.: Apollo, Augustus, and the Poets. Cambridge 2009, 26-28 and passim, who speaks of "Octavianic patron Apollo as god of ordered calm and civilized restraint in opposition to Bacchus the deity of drunkenness and oriental excess". Also GRAF (n. 4) 127-128.
} 
Such notions have become the axiom of a subsequent syllogism which seems to be the basis of numerous studies over the last few decades, which are, consequently, strictly deductive: an opposition Apollo/Dionysus is at the basis of the Augustan world (axiom) and therefore Dionysus's presence therein is problematic, something to undermine, or to bypass, or - in the best of cases - something to explain or justify, ${ }^{10}$ often in terms of a rehabilitation or re-appropriation of Dionysus by Augustus. ${ }^{11}$

David Castriota $^{12}$ was the first to challenge this very pervasive theory of the polarity Apollo/Dionysus within Augustus's ideology. He observes the significant presence of Dionysus and of Dionysiac motifs in Augustan art and literature and rightly points out many inconsistencies within the highly polarised scholarly interpretation of the Actiac propaganda. ${ }^{13}$ He then proceeds to explain from an original perspective the presence of Dionysus in the Augustan world. Castriota argues that the Pax Augusta was consciously created on the harmony between Apollo and Dionysus: both gods were mingled in the conception of a numen mixtum (a formula proposed by Lucan in Phars. V 73-74). Apart from these specific conclusions on the numen mixtum, which were criticised by Sauron, ${ }^{14}$ it is indeed Castriota's emphasis on the presence of Dionysus in the world of Augustus, against the more or less conscious and deliberate scholarly reticence, that undoubtedly marks out the originality and valuable achievement of his research. Stéphanie Wyler, too, has recently promoted this path, by underlining the high amount of Dionysiac motifs in the Augustan Roman art immediately after Actium. ${ }^{15}$ Nevertheless she also seems to be influenced by the idea of a potential threat inherent within a few interpretations of Dionysus - an idea which leads to perceiving something paradoxical in Dionysus's presence within Roman art and by the theory of the rehabilitation of the god. ${ }^{16}$

${ }^{10}$ See, for instance, WeBER, C.: The Dionysus in Aeneas. Classical Philology 97.4 (2002) 322-

${ }^{11}$ See, for instance, SMiтH, A.: In Vino Civitas: The Rehabilitation Bacchus in Vergil's Georgics. Vergilius 53 (2007) 52-86 and REED (n. 9). Such a justification is also expressed by insisting on the polyvalence and ambiguity in the ancient world of Dionysus, who could express more or less positive associations.

${ }^{12}$ CASTRIOTA, D.: The Ara Pacis Augustae and the Imagery of Abundance in Later Greek and Early Roman Imperial Art. Princeton 1995.

${ }_{13}^{13}$ CASTRIOTA (n. 12) esp. 89-94.

${ }^{14}$ Who observes that the conception of the numen mixtum was applied only at Delphi and that we do not have elements to claim that it belonged to the religious policy of Augustus: SAURON, G.: Review of Castriota The Ara Pacis Augustae. Gnomon 70 (1998) 350-354 and SAURON: L'histoire végétalisée (n. 3).

${ }^{15}$ WYLER, S.: Réhabilitation de Liber : ambiguités de la condamnation des images dionysiaques, de «l'affaire» des Bacchanales à Actium. In BENOIST, S. - DAGUET-GAGEY, A. (eds.): Un discours en images de la condamnation de mémoire [CRULH 34]. Metz 2008, 229-244. See also WYLER, S.: An Augustan Trend towards Dionysos: Around the 'Auditorium of Maecenas'. In BERNABÉ, A. - HERRERO De JÁuRegui, M. - JimÉnEZ SAN CRistóbal, A. I. - MARTín HERnÁNDEZ, R. (eds.): Redefining Dionysos [MythosEikonPoiesis, Bd 5]. Berlin-Boston 2013, 541-553.

${ }^{16}$ See WYLER, S.: L'acculturation dionysiaque: l'invention d'une altérité. In MAHÉ-SiMON, M. (ed.): Identités romaines. Paris 2010, 194-195. Here she speaks of the existence of a Dionysus "dieu des bacchanales de 186, teinté d'un hellénisme obscur et d'une perversion religieuse et sociale", an idea which she sees in paradoxical contrast with the amount of Dionysiac iconography: "Néanmoins, ces oppositions mises en valeur par la nature et l'importance des documents - et à laquelle on pourrait ajouter le dionysisme oriental d'Antoine - ne doivent pas masquer une réalité beaucoup plus fréquente, pour ne pas dire 
As regards Castriota's interpretation, the conspicuous corpus of visual testimonies he does cite - the Augustan Campana reliefs, frescoes, stuccoes, Neo-Attic marble vessels of the Roman Imperial time, Augustan marble furniture and table-wares (candelabra, cups, silverwares, Arretine wares), votive sculptures, funerary reliefs, fountains $^{17}$ - appears too heterogeneous to be used d'emblée as proof that Dionysus was at the core of the Augustan ideology. As Sauron observes, ${ }^{18}$ the testimonies quoted by Castriota are often heterogeneous as regards nature, place of finding, and chronology. They would thus require more precise methodological distinctions: are they private or public products? Which of them can be interpreted as an expression of particular ideologies? Which are simply the result of the artistic taste of that epoch? Indeed, many of these materials merely replicate old topoi deeply rooted within the Hellenistic and Roman world and imagery: Dionysus/Liber Pater patron of the banquets (along with Aphrodite/Venus); Dionysus/Liber Pater founder of viticulture (and celebrated with Demeter/Ceres, the patroness of grain cultivation); the deified Dionysus who, along with Hercules, evoked eternal life in the funerary context and with whom the dead person identified himself. Indeed, the friezes including Dionysiac plants and Dionysiac features, so often attested in Augustan funerary art or on Augustan banquet-wares, simply continued the previous visual Hellenistic tradition, as Castriota himself recognises. Therefore, can we consider them as proof of a specific success of Dionysus within the Augustan world?

On the other hand, even Castriota's interpretation itself - despite his effective attempts to highlight the inconsistency (even within the Actiac ideology) of the opposition Dionysus vs. Apollo - is, at least to some extent, influenced by these same premises. Indeed, the hypothesis itself of an Augustan "harmonisation" of Apollo and Dionysus presupposes once again the starting axiom of a potential opposition. ${ }^{19}$ As such, this perspective, which leads him to recognise in the entire range of Augustan art and literature a strategy of dissociating Dionysus or Liber from the taint of Antony, ${ }^{20}$ is not very distant from the hypothesis of a "rehabilitation", also rooted in

banale : le fait que, dans la poésie comme dans les arts figurés, la distinction entre les différentes configurations de Dionysos ne se pose pas, du moins pas en ces termes". That Wyler is influenced by the theory of the rehabilitation of Dionysus is suggested by the title of her study itself - "Réhabilitation de Liber". According to Wyler Octavian simply took possession of Antony's symbols: she speaks of "captation de patrimoine symbolique" (WYLER: Réhabilitation [n. 15] 244).

${ }^{17}$ CASTRIOTA (n. 12) chapter II and III.

${ }^{18}$ SAURON: L'histoire végétalisée (n. 3) 63.

19 "There is certainly no doubt that in the period leading up to and following the battle [of Actium] Augustus and his partisans did all they could to develop the image of Antony as foreign, un-Roman, and morally corrupt, the absolute antithesis of Octavian and the Roman conception of order. But it remains unclear how this polarity continued to involve Dionysus once Augustus had triumphed; nor is it apparent that the Augustan response to a Hellenistic, Greek-inspired Antonian program of ruler glorification automatically precluded the assimilation of concepts and themes from the very same source. (...) On the surface, all propaganda - imagery that seeks to convince or compel opinion - is by nature seamless and unequivocal. But beneath the surface is a patchwork comprised of the very contradictions and alternatives that propaganda strives to contain and suppress. Augustan propaganda was no exception, particularly with respect to Apollo and Dionysus or Liber.” CASTRIOTA (n. 12) 89.

20 "The representations of the god [in the Augustan age] relied primarily on the mature, bearded, heavily draped type of Archaic and Early Classical Attic art; the more youthful, effeminate Hellenistic 
the same polarised vision. From this standpoint, I believe that Sauron is correct when he writes: "Castriota ne veut connaître que l'alternative, constamment assénée dans son ouvrage: inclusion ou exclusion, harmonie ou opposition, concorde ou conflit. Mais enfin, comment a-t-il pu lui échapper, alors même qu'il cite abondamment la littérature augustéenne ainsi que de nombreux ouvrages modernes traitant de cette période notamment dans le domaine religieux, que le concept fondamental de l'époque augustéenne dans ce domaine comme dans les autres était celui de hiérarchie (maiestas)?"21

And yet Sauron fails to provide a clear alternative interpretative approach to the presence of Dionysus within the Augustan world, which he himself also admits, even if rather hastily. ${ }^{22}$ Whilst proposing the interpretative category of "divine hierarchy" versus "divine opposition", nevertheless Sauron reaffirms the legitimacy of the deductive interpretation of Augustan art, on the basis of the axiom of an opposition Dionysus/Apollo. ${ }^{23}$ Moreover, Sauron's fierce criticism of Castriota's legitimate attempts to go beyond the interpretative mainstream expresses a certain dogmatism, ${ }^{24}$ while many of the inconsistencies pointed out by Castriota within the highly polarised interpretation of the Actiac propaganda are still awaiting an answer, as we are going to discover in the following paragraph.

\section{An ill-posed method?}

At this point of juncture a specific question arises: when it comes to an overall evaluation of Dionysus in the Augustan Age, to what extent does such an axiomatic and deductive perspective help us? In this deductive interpretation of the Augustan ideology based upon the axiom of an opposition Dionysus vs. Apollo, the axiom itself has been taken for granted far too often. Firstly, it appears to be merely based on the biased and chronologically limited propagandistic trends before Actium. But do we possess

type is rare, and even when it is used, Dionysus is heavily draped, not naked. Here one senses how the god was accommodated to the values and ideals of the new Augustan order, no longer the languid and ecstatic deity associated with Antony, but now a dignified Pater Liber instead." CASTRIOTA (n. 12) 94. Also p. 105: "With Actium behind him, there was no longer any practical advantage for Augustus to prolong the antagonistic dialectic with Antony's Dionysian affiliation; Augustus's real objective would have been to eradicate the Dionysian associations that Antony had promulgated in order to adapt and incorporate the traditions of this god to the new imagery of the Principate". Also p. 106 : "Dionysus was carefully divested of Antonian and Oriental associations and reintegrated as Liber Pater alongside Apollo and the array of other gods and heroes whose precedent and protection collectively asserted the divine underpinnings of the Principate."

${ }^{21}$ SAURON: L'histoire végétalisée (n. 3) 62. Regarding the "hierarchy" of gods in the Augustan age, see also ZANKER (n. 2) 109.

${ }^{22}$ SAURON: L'histoire végétalisée (n. 3) 61.

${ }^{23}$ SAURON: L'histoire végétalisée (n. 3) 58: "D. Castriota veut porter un coup décisif à l'opposition Dionysos/Apollon sur laquelle se fondent de nombreuses études sur l'art augustéen, dont le miennes."

24 "Une telle affirmation [that the vegetal scrolls of the Ara Pacis indicate a harmony between Apollo and Dionysus: see below] procède d'une réécriture paradoxale d'une des périodes de l'histoire antique qui a fait l'objet des plus nombreux et des plus pénétrants travaux au cours de ce siècle." SAURON: L'histoire végétalisée (n. 3) 61. 
any concrete elements - in authors close to Octavian and in the pre-Actium iconography promoted by Octavian - to claim that Octavian, publicly or privately, did actually criticise Dionysus itself? Did a pre-Actium explicitly anti-Dionysiac literature exist? Did an openly anti-Dionysiac pre-Actium iconography exist? Is the replacement of Dionysus's ivy with the laurel on the Eastern coins in $28 \mathrm{BC}$ sufficient to claim this? Was Antony's debauchery - stigmatized by Octavian and his friends - perceived as a fault of Dionysus himself or was it rather considered simply the product of Antony's intemperance? Octavian, undoubtedly, propagandistically emphasised the scandal of Antony's imitation of Dionysus on the basis of an un-Roman and purely Hellenistic custom, by saying, as attested by Cassius Dio (50.25),

He [Antony] shows no respect for our laws and ancestral gods but worships that person [Cleopatra] if she were some Isis or Selene and calls her children Helios and Selene; finally he even calls himself Osiris and Dionysus and from these [titles], just as if he were lord of all the earth and sea, makes a present of whole islands and some of the continents. ${ }^{25}$

Could this accusation not suggest, in fact, that Octavian simply claimed that he respected Dionysus and refused Antony's appropriation of that god? ${ }^{26}$ In other words, Octavian's reproach does not appear to involve Dionysus per se, but simply the man who dared to appropriate the god, according to an un-Roman tradition. This last theme was, of course, particularly fruitful in Italy on the eve of a battle against an Egyptian queen. If Dionysus had not been a prestigious god according to Octavian and the Romans, then no charge of impiety would have been addressed to Antony.

Indeed, Octavian's initiation into the Eleusinian Mysteries in $31 \mathrm{BC}$, attested by Cassius Dio (51.4. 1), can quite easily be interpreted as a claim of the illegitimacy

${ }^{25}$ Translation provided by SCOTT: Octavian's Propaganda (n. 1) 136-137.

${ }^{26}$ This idea is to some extent echoed by SCOTT: Octavian's Propaganda (n. 1): "Here we have the tradition of an active propaganda directed by Octavian against Antony, with a special thrust at his identification with Osiris-Dionysus. Octavian in making his appeal to the Romans, to Western civilization, seems to have taken a very definite stand. Dio represents him as openly ridiculing in the most scathing language the conception of Antony as Osiris-Dionysus - the very idea that Antony is anything but a mortal become slave to a woman. The only resemblance between Antony and his favourite god would seem to be that the triumvir had become a reveler and wine-sot" (p. 137); "Our sources, moreover, point to Octavian's emphatic denial in the West of the existence of any divinity in the person of Antony or of any identification of Antony with Dionysus" (p. 141). The scholar, however, adds: "The Romans, many of them at least, must have been rather hostile to the Dionysiac cult in the first place, if we may infer a continuance of the hostility shown in the terms of the senatus consultum de Bacchanalibus of $187 \mathrm{BC}$. The idea of a new Dionysus must have brought to the minds of the Romans their enemy Mithradates Eupator and the weak drunkard Ptolemy Auletes." Here we find a root of Mannsperger's theory of "chronical" Dionysiac Hellenistic anti-Roman tendencies and correspondent Roman reactions: the idea that Dionysus per se - or at least some versions of Dionysus - was a problematic figure for the Romans and the syllogism that since Antony identified himself with Dionysus, Octavian must have opposed the god tout court ("Octavian could never cause or permit himself to be designated as a new Dionysus, the god whose cult he had tried to discredit in the West and East." SCOTT: Octavian's Propaganda [n. 1] 140). On the inconsistency of Mannsperger's theory regarding the Bacchanalia, see MASTROCINQUE, A.: Bona Dea and the Cults of Roman Women. Stuttgart 2014, who demonstrates that the senatus consultum against the Bacchanalia was by no means a measure against a "Hellenistic perverted" Dionysus. 
of Antony's appropriation of Dionysus, as suggested by Jane Clark Reeder. ${ }^{27}$ A similar attempt, as claimed by Castriota and by Stéphanie Wyler, ${ }^{28}$ may have happened on the eve of Actium, and an echo of this could well be recognized in several stories reported by Plutarch. In particular, on the Acropolis of Athens a storm was told to have blown down a statue of Dionysus along with the statues of Attalos and Eumenes of Pergamon, great worshippers of Dionysus, which had been re-inscribed with the name of Antony (Antony 60. 2-3). A further story (Antony 75. 3-4) was about the thiasos of Dionysus which was said to have left Alexandria before Octavian entered into the town. If these anecdotes were in fact produced within Octavian's circle, as suggested by Rose, ${ }^{29}$ they would confirm that Octavian intended to claim the illegitimacy of Antony's appropriation of Dionysus.

The enemy of Augustus had to be Cleopatra and her vices. He did not have any wish to present his victory as a triumph in a civil war against Antony. Augustus triumphed in $29 \mathrm{BC}$ over Cleopatra, and not over Antony. If he indeed did not intend to wage war openly against the Roman triumvir, how could we believe that he and Apollo had waged war against Dionysus? As Wyler underlines, in the ancient world "on ne condamne pas un dieu ou une image sacrée". ${ }^{30}$

Besides, if Antony was wrong in his excessive Dionysism, it stands that his wife Octavia was wrong as well. Indeed, she was represented on a few cistophori of Asia Minor in a form which evoked the image of Ariadne, in the same way as Antony evoked Dionysus. ${ }^{31}$ As such, is it genuinely consistent to uphold that Octavian argued against his own sister Octavia? Or are we really to believe that he made a distinction between her Dionysism and that of Cleopatra? Could such hypotheses really stand up to scrutiny?

Thus far there is one further aspect, also underlined by Castriota, which has yet to be explained. If the core of Octavian's Actiac propaganda had been the opposition Apollo vs. Dionysus, why is it that the latter god failed to appear among the gods defeated by Octavian in Vergil's portrayal of Actium (Aeneid VIII 696-706)? Why should

${ }^{27}$ ReEDER, J. C.: Typology and Ideology in the Mausoleum of Augustus: Tumulus and Tholos. Classical Antiquity 11 (1992) 292, n. 169. Under this perspective it is worth considering that when Mithridates and his allies attempted to use Dionysus to undermine Roman authority in Asia, the Romans responded by reclaiming Liber as their very own, as recalled by CASTRIOTA (n. 12) 93. Something analogous happened during the Social War. Indeed the Allies used the image of Liber, traditional supporter of civic freedom, in order to express their opposition against the Roman oppressor and Rome answered with a coin which similarly depicted the god: WYLER: Réhabilitation (n. 15) 239-240. Again, we see the inconsistency of Mannsperger's ideas.

${ }^{28}$ WYLER: Réhabilitation (n. 15) 240-241.

${ }^{29}$ Rose, H. J.: The Departure of Dionysus. Annals of Archaeology and Anthropology 11 (1924) 25-30. Contra SCOTT: Octavian's Propaganda (n. 1) 135, who thinks of an Alexandrine origin.

${ }^{30}$ WYLER: Réhabilitation (n. 15) 243.

${ }^{31}$ BuRnett, A. - Amandry, M. - Ripollès, P.: Roman Provincial Coinage. London-Paris 1992, nr. 2201; TONDRIAU, J. L.: Romains de la République assimilés à des divinités. Symbolae Osloenses 27 (1949) 131. Cf. GARCÍA Vivas, G. - Alonso TronCoso, V.: Octavia versus Cleopatra: immagine della donna e confronto culturale. In GeHRKE, H.-J. - MASTROCINQUE, A. (eds.): Roma e l'Oriente nel I secolo a.C. (acculturazione o scontro culturale?). Atti del convegno humboldtiano Verona, 19-21 febbraio 2004. Cosenza 2009, 11-34, esp. 20-23. 
Vergil have missed such an opportunity? The poet could have at least mentioned the Egyptian Osiris, so as to avoid a direct mention of Dionysus who, after all, had been part of the Roman pantheon for centuries. Indeed, the presence of Osiris would be sufficient to evoke Dionysus, with whom he had long been identified. And yet, there is no mention of Osiris either, while Anubis is the only Egyptian god mentioned among the monstrous and theriomorphic deities that supported Antony and Cleopatra. ${ }^{32}$

The representation of the dispute over the Delphic tripod between Apollo and Hercules in Apollo's temple on the Palatine hill is a further element which could be mentioned by the supporters of the ontological polarity Apollo vs. Dionysus and Octavian's consequent potential dislike towards Dionysus. Here, although Hercules might well represent Antony, who considered the hero the ancestor of his family, and the scene is interpretable as an allusion to Actium, ${ }^{33}$ the competition appears highly noble and respectable. But what is mostly remarkable is that Dionysus does not appear where he would be mostly expected, according to the perspective which prevails among the modern scholars. These are only a few of the many questions and dilemmas which still require clear answers from among the supporters of the thesis of a potential anti-Dionysism in Octavian's propaganda. ${ }^{34}$

Apart from the specific historical circumstances of Actium, I believe that interpretations as those expressed by Mannsperger and Joseph Reed regarding a "longstanding suspicion and fear of Bacchic mystery cults as dangerous and un-Roman" are somewhat weak. ${ }^{35}$ Such interpretations assume two opposite and static semantic fields: one represented by Dionysus, Disorder, Innovation, Pleasure and the East, with the second including, instead, Apollo, Order, Austerity and the West. All this seems to be too rigid and highly debatable. A schematisation like that presupposes a rather static and "manichean" interpretation of these gods, one that - far from belonging to ancient authors and monumental evidence - seems to have been conceived within the minds of modern scholars.

No doubt, Octavian's circle, in its pre-Actium propaganda against Antony, did create an opposition between two antithetic ways of life and morals, respectively embodied by Octavian and Antony. But can we label tout court these polar ways of life as Apollonian and Dionysian? And which Dionysus and Apollo are we actually dealing

\footnotetext{
32 "No evidence suggests that Dionysus was believed to have participated in the battle in any sense." CASTRIOTA (n. 12) 94.

${ }^{33}$ See Kellum, B. A.: Sculptural Programs and Propaganda in Augustan Rome: The Temple of Apollo on the Palatine. In WINKES, R. (ed.): The Age of Augustus. Louvain-Providence 1985, 169-176.

${ }^{34}$ At this point I would like to quote a very meaningful consideration by Robert Alan Gurval, who has specifically studied the impact of Actium upon the politics and the emotions of Augustus's epoch (GuRVAL, R. A.: Actium and Augustus: The Politics and Emotions of Civil War. Ann Arbor 1995). It is not necessary to follow his conclusion that the victory at Actium played an insignificant role in Augustus's ideological programme at the beginning of his regime: the perspective he opens is still very instructive and consistent with my idea that the role of Dionysus in those events has been misunderstood and overemphasised by most interpreters: "The scenario that has been widely imagined for the period of the Triumvirate, where rivals waged war through their surrogate divine patrons (Neptune and Sextus Pompey; Hercules, later Dionysus, and Antony; and Apollo and Octavian) has been exaggerated and distorted." (p. 9).

${ }^{35}$ Specific objections to these generalisations are recalled, e. g., by CASTRIOTA (n. 12) 91-93, with bibliography.
} 
with here? Regarding Dionysus, Dionysus/Liber Pater was an ancient and very highly prestigious god in the Roman pantheon. No doubt, the Dionysus of Antony's ceremonies and ideology was perhaps more Hellenistic than Roman. But does this allow us to classify the Hellenistic Dionysus as a symbol of potential disorder? What should be said, then, of the Dionysus who fights at Zeus's side against the Giants on the altar of Pergamon, a theme which was also recalled by Horace (Carm. II 19)? Furthermore, which Bacchic mystery cults are we actually referring to? If Augustus genuinely wished to discredit the mystery cults of Dionysus, why then did he become an initiate into the Eleusinian Mysteries, where the cult of Dionysus-Iakchos played such a vital role $?^{36} \mathrm{He}$ attended these mysteries on two occasions, and the first time was precisely in $31 \mathrm{BC}$. We have to wait for Hadrian before we find another Roman Emperor initiated at Eleusis.

Moreover, regarding the schematization "Roman versus not-Roman", Octavian's Apollo was hardly an "Apollon romain", but rather a god with Hellenic features, as pointed out by Freyburger. ${ }^{37}$ I believe Castriota is correct in suggesting that the Augustan response to a Hellenistic, Greek-inspired Antonian programme of glorification did not automatically exclude the assimilation of concepts and themes from the same source. This scholar observes, for instance, that, although Octavian's choice of Apollo as a patron has been sometimes interpreted as a rejection of foreign Greek imagery, by doing that Octavian simply followed what had long been, for example, the cornerstone of royal Seleucid propaganda. ${ }^{38}$ Therefore, it is clear that we cannot accept the theory (expressed, e. g., by Mannsperger) that Dionysus must have been rejected by Octavian as un-Roman and a highly threatening god simply because he had been the model of Mithridates, the great enemy of Rome. Indeed, the Seleucids had been great enemies of Rome, as well!

It becomes evident that the conception of an opposition between Dionysus-innovation-East and Apollo-tradition-West is methodologically false and is by no means supported by any documental evidence. More rigorous methodological premises and distinctions are clearly required. ${ }^{39}$ Karl Galinsky puts forward an effective answer to all these considerations and the need of abandoning, finally, the canonical polarised vision: "We should not overemphasize, let alone narrow down, the role of Apollo because of Octavian's struggle against Antony. The schema Apollo versus Dionysus goes back to Nietzsche, who saw in it the key of Greek civilisation, but it is another dichotomy that works with only limited success in the Augustan context. Antony styled himself as the "New Dionysus" in the East, but there is no evidence that this riled the inhabitants of Roma and Italy: the cult of Dionysus, identified with Bacchus

${ }^{36}$ See, among others, Sfameni Gasparro, G.: Misteri e culti mistici di Demetra. Roma 1986, 144-122. Also CASTRIOTA (n. 12) 83-85, with bibliography.

${ }^{37}$ FREYBURGER (n. 9) 27.

${ }^{38}$ CASTRIOTA (n. 12) 89-90.

39 Again, Castriota's criticism towards the shared scholarly approach appears to be more than legitimate: "What matters here is whether modern scholars take the Augustan counter-propaganda or ideology at face value, or whether they are willing to probe more deeply for the underlying realities that shaped the way this ideology evolved and functioned." CASTRIOTA (n. 12) 89. 
and Liber, kept enjoying great popularity. Dionysus is a frequent theme in both Augustan poetry (...) and Augustan art."40

In other words, does a polarised and deductive interpretation help in evaluating the role of Dionysus under Augustus? When it comes to analysing the roles and the meanings of Dionysus within the Augustan world, an inductive perspective, free as far as possible from every possible conceivable prejudice, appears far more preferable. The starting point of such an alternative method is the collection of Dionysiac evidence under Augustus, through which its interpretation and evaluation will come as a natural consequence. In the following pages, far from being exhaustive and without dealing with the complex question of the cult, ${ }^{41}$ I will focus on a handful of these testimonies I consider particularly meaningful as concerns the various roles and themes Dionysus expressed within Augustan art and literature. Moreover, several of these are all the more significant for having aroused academic debates which I believe are particularly emblematic as far as the very same diffusion of this prejudicial attitude towards the Augustan Dionysus is concerned.

\section{AUGUSTAN DIONYSUS IN A PUBLIC DIMENSION}

The primary aspect worth considering is the variety of ways Dionysus was celebrated by authors particularly close to Augustus. ${ }^{42}$ Vergil, for instance, in Aeneid VI 791-

${ }^{40}$ GALINSKY, K.: Continuity and Change: Religion in the Augustan Semi-Century. In RÜPKE (n. 3) 76.

${ }^{41}$ In a further study of mine I have taken into account a few aspects of Dionysiac cults under Augustus (SCAPINI, M.: Le stanze di Dioniso. Contenuti rituali e committenti delle scene dionisiache domestiche tra Roma e Pompei [ARYS anejos, vol. VI]. Madrid 2016). A sign of an official positive attitude of Augustus towards Dionysus is the beginning of the restoration of the ancient and prestigious temple of Ceres, Liber and Libera on the Aventine Hill. Nevertheless, this event could be merely interpreted as a natural consequence of the overall Augustan promotion of the traditional cults. Moreover, it must be observed that the temple was re-consecrated only under Tiberius (Dio. Cass. 50. 10; Tac. Ann. II 49). As we have seen, this apparent Augustan negligence towards the cult of Dionysus should not be connected to a presumed anti-Dionysism by the Princeps, an anti-Dionysism which, as demonstrated, can be by no means proved. Rather, it could be explained as a confirm that the Augustan ideology implied a hierarchy of gods, according to which some gods were more considered than others, a phenomenon underlined, as we have seen, by both Sauron and Zanker. Nevertheless, the evaluation of the public cult of Dionysus under Augustus must take into account a fundamental fact which Stéphanie Wyler has recently underlined: the Dionysism was in the Republican Rome an "affaire privée": although an official cult related to the Aventine temple of Ceres, Liber and Libera existed, along with the important public feast of the Liberalia, the core of the Dionysiac cult was represented by the private thiasoi (WYLER, S.: Le dionysisme dans la villa: initiation familial ou contre-modèle social ? In GALLAND, P. - LÉVY, C. [éd.]: La villa et l'univers familial dans l'antiquité et à la Renaissance. Paris 2008, 61. See also WYLER: Réhabilitation [n. 15] 243). As such, the absence of a particular emphasis on the official cult of Dionysus within Augustan Rome should not be taken as a proof of the fact that the official Augustan ideology discredited Dionysus. The strong official promotion of Bona Dea cult in Rome by Empress Livia confirms that the popularity of the Dionysiac cults was by no means affected under Augustus. Indeed, as underlined by the scholars who studied the Bona Dea and as I had pointed out in my book mentioned above, this goddess was strictly linked with the myth of Dionysus (Brower, H. H.: Bona Dea. The Sources and a Description of the Cult. Leiden 1989, esp. 340-344) and her cult had a deep Dionysiac character: see MASTROCINQUE (n. 26).

42 This theme was already evaluated by Castriota and other scholars. Regarding Dionysus's presence in the poems of "Augustan" poets see, e. g., Miller, J. F.: Ovid's Liberalia. In HerberT-Brown, 
805 portrays Bacchus as one of two mythical analogues for the Princeps, when Anchises parallels the imperial conquests with those of the god, conqueror of the Indians:
(...). Not even Hercules travelled through so broad a span of the earth, although he shot the swift, bronze-footed deer, pacified the Erymanthian groves, and made the Hydra of Lerna tremble before his bow.
Nor did conquering Liber, guiding down his team of tigers with vine-woven reins from the peak of Mount Nysa. ${ }^{43}$

The Indian triumph of Dionysus was the archetype of all the Greek and Roman victories in the East, from Alexander the Great onwards. Moreover, Dionysus - along with Hercules and other heroes traditionally conceived as great benefactors of Mankind, like the Dioscouri - also encompassed the themes of royalty and that of civilisation. Consistently, with his role of benefactor and conqueror, in the Hellenistic and then in the Roman world, this god became a fundamental reference for the apotheosis, exactly like Hercules and other civilising heroes (for the Romans especially Romulus/Quirinus) who had obtained the reward of immortality by means of their benefactions. ${ }^{44}$ A further association of the Princeps with Dionyus/Liber (along with the Dioscouri), proposed by Horace (Epistles II 1), concerns precisely this theme of civilisation and benefactions towards Mankind:

Romulus, father Liber, Pollux and Castor, who, after mighty deeds, were welcomed into the temples of the gods, so long as they had care for earth and human kind, settling fierce wars, assigning lands, and founding towns,

G. (ed.): Ovid's Fasti. Historical Readings at its Bimillennium. Oxford 2002, 199-224; FABRE-SERRIS, J.: Figures romaines de Dionysos à la fin du $\mathrm{I}^{\mathrm{er}}$ siècle av. J.-C. In DUITS, R. - QuIVIGER, F. (eds.): Images of the Pagan Gods. Papers of a Conference in Memory of Jean Seznec [Warburg Institute Colloquia 14]. London 2009, 281-296; Schiesaro, A.: Horace's Bacchic Poetics. In Houghton, L. B. T. - WYKE, M. (eds.): Perceptions of Horace. Cambridge 2009, 61-79; FELDHERR, A.: "Dionysiac Poetics" and the Memory of Civil War in Horace's Cleopatra Ode. In BREED, B. - DAMON, C. - RossI, A. (eds.): Citizens of Discord: Rome and Its Civil Wars. Oxford 2010, 223-232; CuCCHIARELLI, A.: Ivy and laurel: divine models in Virgil's "Eclogues". Harvard Studies in Classical Philology 106 (2011) 155-178; FUHRER, T.: Inszenierungen von Göttlichkeit: die politische Rolle von Dionysos/Bacchus in der Römischen Literatur. In Schlesier, R. (ed.): A Different God?: Dionysos and Ancient Polytheism. Berlin 2011, 373-389; Freyburger, G.: Liber-Bacchus dans la poésie augustéenne : du passé de Rome au temps d'Auguste. In Devillers, O. - Flamerie de Lachapelle G. (eds.): Poésie augustéenne et mémoires du passé de Rome : en hommage au professeur Lucienne Deschamps. Paris-Bordeaux 2013, 93-99; MAC GÓRÁIN, F.: The Mixed Blessings of Bacchus in Virgil's Georgics. Dictynna: Revue de Poétique Latine 11 (2014).

${ }^{43}$ Translation by Patricia Johnston.

${ }^{44}$ On these themes see, among others, ScOTT, K.: The Identification of Augustus with RomulusQuirinus. TAPhA 56 (1925) 82-105. More recently, see BoswORTH, B.: Augustus, the Res Gestae and Hellenistic Theories of Apotheosis. JRS 89 (1999) 1-18 and GREBE, S.: Augustus' Divine Authority and Vergil's Aeneid. Vergilius 50 (2004) 35-62, and in particular 52-53. That these themes, and the tradition of the encomiastic catalogue of deified heroes, were rooted in the Hellenistic tradition is also underlined by CASTRIOTA (n. 12) 99-104. The strict connection between the Eastern triumph - ontological attribute of Dionysus - and the apotheosis has been recently underlined by Robert F. Dobbin, who focuses in particular on the deification of Julius Caesar (DoBBIN, R. F.: Julius Caesar in Jupiter's Prophecy, "Aeneid" Book 1. Classical Antiquity 14 [1995] 5-40). 
lamented that the goodwill hoped for matched not their deserts. He who crushed the fell Hydra and laid low with fated toil the monsters of story found that Envy is quelled only by death that comes at least. For a man scorches with his brilliance who outweighs merits lowlier than his own, yet he, too, will win affection when his light his quenched. Upon you, however, while still among us, we bestow honours betimes, set up altars to swear by in your name, and confess that nought like you will hereafter arise or has arisen ere now. ${ }^{45}$

The parallelism Augustus/Liber, along with other traditional deified heroes, also occurs in Horace's Odes (III 3. 9-17). Indeed, the connection between deification and benefactions to Mankind, including the Dionysiac triumph - evoked by the Dionysiac chariot with tigers -, is quite apparent in the following lines:

It was through this quality that Pollux and roving Hercules after a long struggle reached the fiery heights; reclining in their company, Augustus will drink nectar with rosy lips. Through this, Father Bacchus, your tigers deservedly carried you aloft, pulling the yoke with their wild necks; through this Quirinus was saved from Acheron by the steeds of Mars (...). ${ }^{46}$

From these texts we can conclude that the Augustan ideology inherited the traditional Hellenistic theme of Dionysus as a prototype of conqueror and benefactor of Mankind and, consequently, the conception of Dionysus as a fundamental model for the apotheosis. ${ }^{47}$ The role of Dionysus in the deification had already been illustrated by the Vergilian 5th Eclogue: the apotheosis of Daphnis, the mythical Arcadian shepherd initiated into the Dionysiac mysteries and symbolic alter ego of Caesar, is presented under Dionysus's patronage. Here Dionysus represents fertility and life. ${ }^{48}$ The text, published in the early 30 's BC, confirms that these themes were well rooted in contemporary Rome.

The inclusion of Dionysus, as a benefactor of Mankind, within the Augustan world is confirmed by Vergil's Georgics, composed between 36 and 29 BC. More precisely, Bacchus is celebrated here, in his traditional association with Ceres, as patron of the vine cultivation, immediately in the opening lines of the poem (I 1-7):

What makes the cornfield smile; beneath what star

Maecenas, it is meet to turn the sod

Or marry elm with vine; how tend the steer;

What pains for cattle-keeping, or what proof

${ }^{45}$ Translation by H. Rushton Fairclough.

${ }^{46}$ Translation by Niall Rudd.

${ }^{47}$ See the bibliography mentioned in n. 44 and, again, DoBBIN who, by quoting precisely the examined Vergilian passage of the 6th book of Aeneid, confirms that the association of Eastern victory and deification is inherited by the philo-Augustan poetry. As underlined by Francis Cairns (CAIRNS, F.: Sextus Propertius the Augustan Elegist. Cambridge 2006, 333-334 and 366) the theme of Dionysus forerunner and model of Augustus in his role of world-conqueror appears in Propertius and Ovid too.

${ }^{48}$ On these themes, see the already quoted SMITH (n. 11) part. 61-63, with bibliography. 
Of patient trial serves for thrifty bees; Such are my themes. O universal lights Most glorious! ye that lead the gliding year Along the sky, Liber and Ceres mild, etc. ${ }^{49}$

The second book of the Georgics is specifically dedicated to this god and to the celebration of wine: the poet emphasises, in particular, the civilizing features of viticulture. The theme therein of the negative effects of excessive drinking, which also appears in the Georgics, does not actually undermine the overall positive role of Dionysus in this work.

As underlined by Alden Smith, ${ }^{50}$ the celebration of the civilising role of Dionysus also occurs in Horace's Ode 19 of his second book, which is again dedicated to Bacchus. Here the god appears as a calming power that flanks Jupiter against the Giants and is able to assuage the bite of Cerberus (Carm. II 19). ${ }^{51}$

These appearances of Dionysus in Augustan literature have been often interpreted as hints of a progressive rehabilitation of Dionysus after Actium, or of the usurpation of Antony's Dionysus by Octavian. ${ }^{52}$ But we have now seen how these inter-

${ }^{49}$ Translation by J. B. Greenough.

${ }^{50}$ SMiTH (n. 11) 52-86.

${ }^{51}$ SMITH (n. 11) 82-83: "Although you were said to be more suited to dancing and joking and sport, you were not regarded as sufficiently suited to battle; still you were the same in the midst of peace and war. Harmless Cerberus, lightly brushing you with his tail, saw you decorated with a golden horn and he touched your reluctant feet and legs with this three-tongued mouth" (translation by A. Smith). On the celebration of Bacchus as an agricultural deity within Augustan poetry see also CAIRNS (n. 47) 367-368.

${ }^{52}$ SMITH (n. 11) for instance, focusing on the positive role of Dionysus in the Georgics, explains his interpretation with the following considerations: "How is it that in the Aeneid Bacchus can offer a positive parallel to the Emperor? This is the same god whose cult was banished from Rome in 186 BC because of the immoral behaviour engendered by it, described colourfully by Livy (39. 13-14); accordingly, Bacchus' image might well have appeared to be "dangerous and un-Roman". Even if Bacchus' divine status was never in question in the West, the way that Bacchus was appropriated by Octavian's Eastern rival would have presented a challenge for Octavian early in his career and may have made the overall image of the god less than entirely palatable. As the title of this paper suggests, I believe that the Georgics offer important piece of evidence concerning the way Bacchus' poetic status is transformed in the early to mid-Augustan period, which roughly constitutes the time between the publication of the Eclogues and completion of the Aeneid. (...) Even though both Bacchus and Hercules had hitherto been associated with Marc Antony, the time the by Aeneid is nearing completion in $19 \mathrm{BC}$, Bacchus' potency and ubiquity can be seen as positive qualities, qualities imputed not to just any Roman leader, but to Augustus Caesar himself (pp. 53-54). (...) Vergil has rehabilitated Bacchus' image, and the Georgics has had everything to do with this rehabilitation. Bacchus had been Antony's deity. Yet Bacchus has now been, along with everything else Antony controlled, repossessed by Octavian" (p. 82). The same concept of "rehabilitation" of Dionysus under Augustus also appears in E. BATINSKI (Horace's Rehabilitation of Bacchus. The Classical World 84.5 [1991] 361-378, esp. 372-377), who analyses in particular the celebration of Bacchus as god of poetry in Horace in his Odes I-III: "Antony's political symbol has been transmuted and absorbed into Augustan propaganda to support the divinity of the Emperor" (p. 374). CAIRNS (n. 47) 365-369 follows an analogous path speaking of "religious' difficulties which were a legacy of the final Civil War" and saying that Bacchus was initially a problematic deity for Augustan poets after Antony's identification with the god. As a consequence, this scholar, too, speaks of a rehabilitation and reintegration of Bacchus into the Augustan consensus, and believes that this goal was in part achieved by presenting the god not as an Eastern deity, but as the Italian and Roman agricultural Bacchus/Liber. This interpretation strictly recalls that expressed by Smith. On the other hand, the concept of "rehabilitation" is replaced with that of 
pretations are somewhat aprioristic and swayed by the prejudice of a potential antiDionysism of Octavian in the mood of Actium. Indeed, some of these texts belong to a period which pre-dates or immediately follows that battle: as such can we still speak of a progressive "rehabilitation" of Dionysus? By adopting an inductive perspective, we should rather interpret these testimonies as unquestionable proof that Dionysus was not only wholly integrated within the Augustan imagery but that he could even provide a comparandum for Augustus - in his various and traditional roles of triumphant god, benefactor of Mankind, god of civilization and patron of vine cultivation. Such testimonies also underline how the perception of these prestigious Dionysiac aspects and functions was absolutely independent of Antony. ${ }^{53} \mathrm{We}$ have also seen that, while a few of these themes were deeply rooted within the Roman tradition, as in the case of the celebration of Liber along with Ceres as patron of viticulture, other themes had their origin within the Hellenistic world. ${ }^{54}$

A number of Augustan iconographies which also evoke the topos of the Dionysiac triumph seem to confirm this impression. They belong to a few coins celebrating

\footnotetext{
"usurpation" in the already mentioned work by REED (n. 9). The scholar reflects in particular on the passage of the quoted Aeneid VI 801-805: "It is not a coincidence that the two gods to whom Augustus is compared are the very two whom Antony cultivated and emulated. On their surface these lines slight the Antonian gods' imperial prowess in favour of Augustus' (...). There may be a dig here at the failure of Antony's Parthian campaign, especially if this passage postdates Augustus' recovery of Crassus' lost standards in 20 BC. But in a deeper sense, Augustus is not contrasted with Hercules and Bacchus; he does not merely surpass, but usurps their greatness. It is as if with the victory at Actium and the suicides of his opponents, Octavian were going to take on Antony's role, becoming a sort of improved Antony, a superAntony who is a worthier heir of Alexander. That is why these lines leave behind everything Roman and judge Augustus in terms of the Greek East - Antony terms" (p. 413). It is clear that the starting hypothesis on the basis of these studies is that since in the years close to the battle of Actium Octavian's adversary identified himself with Dionysus, Octavian must have had necessarily potential problems with Dionysus. The idea of an usurpation of Dionysus's deeds by Augustus has been recently expressed by T. Luckritz Marquis, too (LuCKRITZ MARQuIS, T.: Transient Apostle: Paul, Travel, and the Rhetoric of Empire. New Haven 2013, 81-82): he interprets Vergil's passage of the 6th book of Aeneid as a proof that "Vergil refuses to identify Augustus with Dionysus in the style of the Hellenistic and Roman conquerors who had come before. Rather, the new Emperor exceeds the accomplishments of the victorious god and - more to the point - the leaders after Alexander who had availed themselves of Bacchic imagery, Antony being the last in a long line."

${ }^{53}$ As rightly observed by CASTRIOTA (n. 12) 99: "Collectively the Odes and the Epistles [by Horace] demonstrate not only that Liber was an honored deity within the Augustan pantheon, but that he had an established, recurrent function as a mythic analogue for Augustus himself; (...) Nor does it seem that the Antonian connection posed any impediment to the strategy of comparing Augustus directly to Liber." See also DU QUESNAY, I. M. LE M.: Horace and Maecenas. The propaganda value of Sermones I. In WOODMAN, T. - West, D. (ed.): Poetry and Politics in the Age of Augustus. Cambridge1984, 31, who observes that the Augustan poetry simply transferred the analogy with Hercules and Dionysus - already used by Antony - to Augustus himself.

${ }^{54}$ I find a few considerations expressed by Galinsky a very pertinent conclusion of all these considerations. GAlinsky, K.: Augustan Classicism. The Greco-Roman Synthesis. In TITCHENER, F. B. MoOrton JR., R. F. (ed.): The Eye Expanded. Life and the Arts in Greco-Roman Antiquity. Berkeley Los Angeles - London 1999, 180-205: "The basic antithesis [Apollo versus Dionysus, Augustan classicism versus the "unbridled excess of the so-called Hellenism"], (...) which needs to be modified even in its application to Augustan sculpture, is irrelevant to other areas of Augustan culture, such as poetry. One of the central characteristics of the oeuvre of the Augustan poets is their integration of many impulses from Hellenistic poetry" (pp. 180-181).
} 
the Emperor issued by the moneyer Petronius Turpilianus. The first coin type that appeared in $19 \mathrm{BC}$ shows the head of the ivy-wreathed Liber encircled with the name of Turpilianus all around, whereas on the reverse Augustus is depicted on an elephantbiga, with the name Augustus Caesar. ${ }^{55}$ A second type ${ }^{56}$ associates an analogous bust of Liber with a kneeling Parthian. This warrior holds a standard with vexillum, a clear reference to the recovery of the Roman signa in $20 \mathrm{BC}$. They had been kept by the Parthians after Carrhae, and their recovery was also celebrated by Augustus in his Res Gestae. Consistently, the words around the Parthian say "Caesar Augustus sign[a] rece[pta]". A further coin type issued by Turpilianus ${ }^{57}$ shows the head of Augustus and a young and thoughtful satyr sitting on the ground with two flutes on the other side. As Bruhl suggested, the meaning of Dionysus on these coins might depend on a particular link between the gens Petronia and the god. The scholar also observes that Liber could evoke the theme of Libertas: Augustus might therefore be presented here as the patron of the libertas populi Romani. ${ }^{58}$ Nevertheless, since these coins were issued following Augustus's diplomatic successes in the East between 23 and 20 BC, the most logical explanation is that they were mainly aimed at evoking an Eastern triumph, which, as we have seen, was traditionally associated with Dionysus. ${ }^{59}$ These coins are thus mirroring the above mentioned passage from the 6th book of the Aeneid and further strengthen the impression that Dionysus as a conqueror was perfectly integrated within Augustan imagery. On the other hand, the considerations regarding these coins by Zanker seem to be somewhat misplaced and once again rooted in the aprioristic deeply polarised vision of Dionysus and of the Dionysiac themes under Augustus:

No one prevented the mint master of $19 \mathrm{BC}$ from reviving an old tradition in comparing the victor in Parthia with Hercules and even with Dionysus, celebrating his triumph in a chariot drawn by elephants. But the comparison with Dionysus was clearly inappropriate, in the wake of Antony's abuses, and it was never repeated. ${ }^{60}$

Firstly, to my mind the presence of Dionysus within this context must be neither neglected nor underestimated, given the fact that we have to wait until the 2nd century $\mathrm{AD}$ to see once again the god celebrated on imperial coins. ${ }^{61}$ Secondly, can we really assert that Roman people were still obsessed by Antony's memory twelve years after Actium? It seems to be far more preferable to approach these documents from a different point of view, independently from the conflict Octavian/Antony. From this standpoint, these iconographies seem to confirm what we have already learnt from

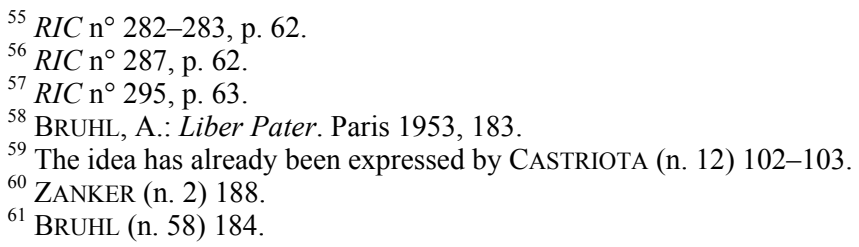


Augustan poets, namely that the Hellenistic ideology of the Dionysiac triumph and apotheosis was definitely consistent with the atmosphere of the Augustan Age. ${ }^{62}$

Concerning the theme of the Dionysiac triumph, a few considerations need to be added. We have seen how the Dionysiac interpretation of the Eastern triumph had originally been adopted by Alexander. As such, from that epoch onwards, the ideal model of Dionysus as a conqueror of India inevitably included a reference to the Macedonian. These themes were inherited by Republican Rome, whose generals, in the 1st century BC, looked alternatively to Dionysus or to Alexander (or to both) when they took part in Eastern campaigns or activities, like Marius, Pompey, Caesar and, of course, Antony. ${ }^{63}$ In the case of Antony, his comparison with Dionysus and Alexander, along with Hercules, in the role of his ideal models, was particularly strict, as Marasco has recently underlined. ${ }^{64}$ As such, the fact that Augustus looked to Alexander as a model, and what is more from the very beginning of his career, furtherly confirms my interpretation: the presence of Dionysus in his Hellenistic role of royal prototype and triumphant conqueror within the Augustan imagery was by no means problematic or paradoxical both before and after Actium.

Indeed, Augustus's interest in Alexander is initially attested by Cicero, who compared the young Octavian with the Macedonian in the Senate a few years before Actium (Phil. 5. 17. 38). ${ }^{65}$ The fact that Augustus looked to Alexander as a model is also demonstrated by his visit to the tomb of the Macedonian in Alexandria and his homage to the relics, soon after Actium (Suet. Aug. 19. 1, Dio 51. 16. 5). In particular, according to Cassius Dio, when his guides offered to show him the tombs of the Ptolemaic sovereigns, Octavian answered that he had come to see a king and not dead people. Therefore we have every right to believe that Alexander was a model of royalty for Augustus, too. Augustus's mausoleum, whose edification started after his return from Alexandria ${ }^{66}$ and which is wholly consistent with the Hellenistic aesthetics and inspired by Hellenistic royal monuments (such as the Mausoleum of Halicarnassus and perhaps by Alexander's tomb itself), ${ }^{67}$ is further proof that in around $30 \mathrm{BC}$ Augustus was imbued with, or at least strongly influenced by, the model of Hellenistic royalty. Moreover, Augustus initially used for his official and personal correspondence (in diplomatibus libellisque et epistulis) a seal with the image of Alexander, ${ }^{68}$ before substituting it with his own. Eventually, Pliny recalls that Augustus had sel 1967.

${ }^{62}$ See also WYLER: Réhabilitation (n. 15) 242-243.

${ }^{63}$ See, e. g., Michel, D.: Alexander als Vorbild für Pompeius, Caesar und Marcus Antonius. Brüs-

${ }^{64}$ MARASCO (n. 1) 541-543. The scholar, commenting on the Antonian pamphlet De sua ebrietate, published immediately before Actium, suggests that a strong common denominator on Antony's models was the wine, since Dionysus was its patron and both Hercules and Alexander were told to have been great drinkers.

${ }^{65}$ See ZANKER (n. 2) 39. See also DoBBIN (n. 44), who points out that the parallel with Alexander was revived on the Emperor's behalf.

${ }^{66}$ Zanker suggests 32-28 BC: see ZANKER (n. 2) 72-76.

${ }^{67}$ See REEDER (n. 27). Reeder hypothesises that an important model of the tomb of Augustus was the Arsinoeion of Samothrace. See already BERNHARD, M.-L.: Tombeau d'Alexandre et Mausolée d'Auguste. $R A 47$ (1956) 129-156, quoted by Reeder.

${ }^{68}$ Suet. Aug. 50. 1. 
brought to Rome from Alexandria and placed in his forum two panels depicting Alexander by Apelles, originally intended for Ptolemy I (HN 25. 10. 27, 36. 93-94). ${ }^{69}$ The first panel represented the Macedonian with the Dioscouri and the second Alexander's triumph (no doubt, it must have been a strongly "Dionysiac" representation). Augustus's adherence to the Hellenistic ideology of triumph and royalty, based on the illustrious models of Dionysus/Alexander and further benefactor heroes like the Dioscouri, is evident.

All these testimonies furtherly undermine the assumption that Octavian's antiAntonian propaganda would have involved Antony's models such as Dionysus and, in this particular case, Alexander. On the contrary, Augustus clearly makes a distinction between Antony and Alexander. In $31 \mathrm{BC}$, when the pamphlet De sua ebrietate undoubtedly still circulated, Octavian approved of and respected Alexander's prestige and royalty, despite his fame of a drunkard, and despite his resemblance with the "Indian Dionysus". Therefore, are we really expected to assume that, in those years, Octavian did not make a distinction between Antony and Dionysus? Moreover, can we still think of a programmed attack on the part of Octavian against the monarchic Hellenistic ideology, the Wiederstand gegen die Übergriffe des hellenistischen Herrschertums as Mannsperger claims? ${ }^{70}$ Rather, at best, with respect to these testimonies we could speak of an ontological ambiguity in Augustan ideology, which on the one hand promoted the restoration of mos maiorum and national tradition and on the other adopted themes from Hellenistic royal ideology and aesthetics, as underlined by Jane Clark Reeder regarding in particular Augustus's mausoleum. ${ }^{71}$ And yet, the concept

${ }^{69}$ REEDER (n. 27) 293.

${ }^{70}$ MANNSPERGER (n. 6) 394. The same doubt arises if we focuses specifically on the iconography. As Zanker himself has underlined, Octavian promoted in his portraits the use of the visual formulas typical of the Hellenistic kings even a few years before Actium, and precisely after his victory against Sextus Pompeus - therefore, when Antony's Dionysiac identification and his adherence to the Hellenistic monarchic ideology had already occurred (ZANKER [n. 2] 39). Moreover, again after Naulochus, it is very likely that Octavian chose a Greek chlamys instead of the Roman toga for his victorious parade in Rome, like Alexander and a Hellenistic king, as Zanker also suggests (ZANKER [n. 2] 41-41). The scholar significantly writes, regarding the copies of the first official portrait of Octavian, made around $40 \mathrm{BC}$, that they were images of a Hellenistic king. Therefore, under the point of view of the aesthetics, when we consider the testimonies recalled by Zanker and the mausoleum, explicit Wiederstand gegen die Übergriffe des hellenistischen Herrschertums by Octavian appears neither before nor immediately after Actium.

${ }^{71}$ REEDER (n. 27) 272: "While the tumulus mound was so a familiar feature of the Italian topography to Romans that the architectural entity might be said to reflect the mos maiorum and national tradition in a way analogous to the philological use of the ancient term, the juxtaposition of this tumulus to the towering base and statue of the Emperor, the two monumental features of Hellenistic dynastic implication that Strabo mentioned, might reflect this inherent ambiguity (...) Despite the reassuring gesture of the tree-planted mound, if such it was, the total impact of the monument and its surroundings lay in the direction of Hellenistic dynastic power." A similar idea of ambiguity is also expressed by CASTRIOTA (n. 12) 89 and passim, and, at least as far as the visual imagery is concerned, by Zanker, as we have seen. In particular, whilst commenting on the Hellenistic trait of Octavian's first portraits mentioned above, Zanker underlines how such an ambiguity could become problematic. The scholar believes that these artistic contradictions will be progressively resolved within the Principate, according to a new aesthetics of harmony consolidated by Augustus. Nevertheless, Augustan "classicism" remained open to the persistence of Hellenistic formal traditions: "What governed the choice in each instance was the means of best displaying ethical values" (p. 255). On these themes and on the new Augustan aesthetics, see also the already quoted 
of ambiguity itself comes from a modern perspective, and in this respect it would be worth clarifying what the actual perception of the Romans at that time actually was. Again, the claim of a substantial ambiguity of Augustan messages like these could still hide the perception of a sort of paradox in those cases where the Hellenistic Dionysus appears on Augustus's side. On the contrary, it seems that no paradox was perceived by Augustus's contemporaries, as the mentioned texts and iconographies, dated from the early 30's to the end of the Republican era, clearly demonstrate.

Let us now examine further appearances of Dionysus in the Augustan public works of art, namely the vegetal scrolls of the Ara Pacis. Indeed, they include Dionysiac plants such as the vine and the ivy. Over the last 15 years these scrolls, which most interpreters consider deeply symbolic and therefore much more than a mere decoration, have been at the heart of a strong scholarly debate. I myself find it particularly emblematic as far as the prejudices regarding Dionysus in the Augustan world are concerned. $^{72}$

Following some considerations by Pollini, ${ }^{73}$ Castriota believes in particular that the vegetal scrolls in the north and south floral friezes of the Ara Pacis - which associate these Dionysiac plants with the "Apollonian" acanthus and laurel - is the source which best expresses the conception of the numen mixtum which he ascribes to Augustan ideology. We have seen that the emphasis on this presumed "reconciliation" between Dionysus and Apollo, as the idea behind the "rehabilitation", 74 rests on the modern prejudice of the hostility towards Dionysus by Augustus.

On the other hand, we find the exact opposite interpretation expressed by Sauron. ${ }^{75}$ He considers the floral frieze, which is immediately below Augustus and his relatives, as a "végétalisée" representation of the battle of Actium, consistent with the dynastic message which he in fact ascribes to the whole monument. Then, on the basis of the theme of the competition among plants known in Hellenistic poetry and present in Vergil as well (Ecl. VII 61-64), Sauron believes that the inclusion of laurel and ivy within the vegetal scrolls is aimed at claiming the dominance of Apollo-Augustus over Antony-Dionysus:

\footnotetext{
GALINSKY (n. 54), who underlines the strong Hellenistic component of Augustan visual program. In a recent study of hers focused on Augustus, B. LEVICK (Augustus: Image and Substance. Harlow 2010) speaks, too, of a substantial ambiguity of Augustus's regime and, perhaps, of his character, by pointing out precisely his identification with Dionysus proposed by the poets of his epoch: "This is the man who wanted to be identified with Apollo, but who did not shrink from allowing other identifications, even with deities associated with his rivals, appropriating Hercules, Antony's ancestor, and even his special patron Dionysus" (p. 15).

${ }^{72}$ A quite up-to-date bibliography and description of the scrolls is provided by REHAK, P.: Imperium and Cosmos: Augustus and the Northern Campus Martius. Madison 2006, 105-106.

${ }^{73}$ Pollini, J.: The Acanthus of the Ara Pacis as an Apolline and Dionysiac Symbol of Anamorphosis, Anakyklosis and Numen Mixtum. In MACHATSCHEK, A. - KubelíK, M. - SCHWARZ, M. - FrodL, W. (Hrsg.): Von der Bauforschung zur Denkmalpflege. Festschrift für Alois Machatschek zum 65. Geburtstag. Wien 1993, 181-217.

${ }^{74}$ It is meaningful that Castriota's idea is accepted by SMITH (n. 11), who promotes the idea of a rehabilitation of Dionysus under Augustus.

${ }^{75}$ SAURON: L'histoire végétalisée (n. 3) 43-52. See already SAURON, G.: Le message symbolique des rinceaux de l'Ara Pacis Augustae. CRAI 126 (1982) 81-101, esp. 83-84.
} 
On peut supposer que le lierre et la vigne s'y trouvent en position de végétaux « vaincus » selon l'image virgilienne (nec... vincet...), ${ }^{76}$ tandis que l'acanthe y ferait figure de végétal « vainqueur ». ${ }^{77}$

(...) Les raisons de la compétition entre végétaux dans les rinceaux de l'Ara Pacis tiennent évidemment au fait que s'y exprime la rivalité fondatrice du principat d'Auguste, celle qui avait opposé Marc Antoine, qui s'était proclamé « nouveau Dionysos » dès débuts du triumvirat, au moment de son installation dans la moitié orientale de l'Empire, et le futur Auguste, qui se disait protégé et même fils d'Apollon, (...). ${ }^{78}$

Here we have yet another example of an a priori interpretation that derives from the already examined syllogisms, which are interrelated:

1) since Antony had identified himself with Dionysus before Actium, Augustan Actiac ideology must have opposed Dionysus per se;

2) since Augustan art is rooted in the opposition between Dionysus and Apollo, the presence of Dionysus therein must be problematic.

From these assumptions, in the specific case of the vegetal scrolls, Sauron concludes that since the Ara Pacis mirrors the Actiac ideology, the Dionysiac plants which appear therein must be végétaux vaincus.

Of course it is not my intention to object to the brilliant and very stimulating interpretation of the floral frieze of the Ara Pacis provided by Sauron, nor do I intend to deny a reference to the Actiac ideology that he perceives in the south vegetal frieze. Nevertheless, I cannot help but pose again the question: to what extent can we consider legitimate all these syllogisms? The intensity itself of the debate between both Sauron's and Castriota's interpretations of these scrolls - which includes the obsessive question: is there more of Apollo or more of Dionysus in the floral frieze? mirrors the numerous potential contradictions to which such an axiomatic approach to Augustus's Dionysus inevitably leads. The result is a potentially endless argument and, to some extent, rather pointless. ${ }^{79}$ On the contrary, by adopting an alternative inductive perspective, the presence in the Ara Pacis of Dionysiac plants is interpretable as further confirmation that Dionysiac motifs could in fact appear within contexts

${ }^{76}$ Ecl. VII 61-64: Populus Alcidae gratissima, uitis Iaccho, / formosae myrtus Veneri, sua laurea Phoebo; / Phyllis amat corylos: illas dum Phyllis amabit, / nec myrtus uincet corylos, nec laurea Phoebi. A comment on this eclogue, and more generally on the links between the gods and their arboreal essences in Vergil's poetry, is proposed by CUCCHIARELLI (n. 42).

${ }^{77}$ SAURON: L'histoire végétalisée (n. 3) 44. The same interpretation is followed by FLORY, M. B.: The Symbolism of Laurel in Cameo Portraits of Livia. Memoirs of the American Academy in Rome 40 (1995) 47.

${ }^{78}$ SAURON: L'histoire végétalisée (n. 3) 45.

${ }^{79}$ In this sense I agree with Luigi Sperti who, quoting respectively Sauron and Zanker and, on the other hand, Pollini and Castriota, writes that, on the relationship of Dionysus and Apollo within the Ara Pacis frieze, "si è discusso, in verità oltre i limiti del ragionevole" (SPERTI, L.: Il fregio vegetale dell'Ara Pacis. Engramma 76 [Dicembre 2009], http://www.engramma.it/eOS/index.php?id_articolo=381). 
imbued with the official Augustan ideology and even with the Actiac ideology itself, should we chose to follow Sauron's idea. ${ }^{80}$

\section{THE AUGUSTAN DIONYSUS IN THE PRIVATE SPHERE}

The analysis of the perception of Dionysus in the Augustan period can be extended to the private sphere, and to the domestic iconography in particular, where the presence of Dionysus is particularly conspicuous. ${ }^{81}$ Still, a premise is indeed required, since it is apparent that a message expressed in the public sphere cannot have the equivalent value of a message expressed in a private context. As Zanker effectively underlines, in the late Roman Republic, throughout the process of Hellenisation, a strong opposition emerged between the public and the private sphere: the private villas became the refuge of aristocrats who looked to the Hellenistic culture and its ideal of luxury. ${ }^{82}$ Nevertheless, as Zanker points out, once the Augustan ideology - which included the perception of the Augustan epoch as a renaissance and a new saeculum aureum managed to integrate the Greek heritage into its aesthetics, this dichotomy was overcome. ${ }^{83}$ Greek mythology, art and ideals became a model of life for wider social strata, while the official ideology did enter into the private sphere. ${ }^{84}$ From this point of view, we should interpret the overwhelming presence of Dionysus in the private iconogra-

${ }^{80}$ See, for instance, Sperti's interpretation (n. 79): "Nell'Ara Pacis (...) la compresenza di piante e di animali simbolici (...) andrebbe letta come segno metaforico della concordia degli dei e dunque della sua conseguenza terrena, la Pax Augusta." Also WYLER: Réhabilitation (n. 15) 243. A study of Charles Brian Rose published in 1990 (Rose, C. B.: Princes' and Barbarians on the Ara Pacis. AJA 94 [1990] 453-467) recognises a further element in the Ara Pacis which may evoke the Dionysiac sphere. Behind the child next to Agrippa, commonly identified with young Gaius appears a woman. She wears a royal diadem bound at the top of the forehead, a placement which, according to Rose, is paralleled only in representations of Dionysus, Ariadne, and the Maenads. His conclusion is that we are dealing with an Eastern queen, whose kingdom or family was in some way connected to Dionysus. He thinks in particular of Dynamis, the daughter of Pharnaces and the granddaughter of the great devotee of Dionysus Mithridates Eupator. The princess married in 14 BC Polemon, new king of the unified kingdoms of Pontus and the Bosporus after the intervention of Agrippa in that region (D. C. 54. 4-10). Nevertheless a year after the marriage was broken and, according to Rose, in 13 BC Dynamis may have accompanied Agrippa to Rome and remained there until Polemon's death. Therefore her presence here would fit well with Agrippa's political activities immediately prior to the constitution of the altar. In particular the presence of the granddaughter of Mithridates, fierce enemy of the late Roman Republic, among the members of the imperial family would have been a clear indication that peace between Rome and the Bosporan/Pontic kingdom had been definitively achieved. If we followed Rose's interpretation we would have a new, interesting, example of the reception of the Hellenistic royal Dionysism in the Augustan Rome. At the time of the consecration of the Ara Pacis an Ariadne-like queen is allowed to flank with all the honours Augustus and the members of his family.

${ }^{81}$ We have seen how Castriota has singled out many Dionysiac motifs within the Augustan domestic furniture. As WYLER underscores (n. 41, 61 and n. 15, 243-244), between the late Republic and the Empire there was an invasion of the domestic spaces by Dionysiac images and motifs. See also WYLER, S.: Dionysiaca aurea: the development of Dionysiac images from Augustus to Nero. Neronia electronica 2 (2012) 3-19.

\footnotetext{
${ }^{82}$ ZANKER (n. 2) 25-31.

${ }^{83}$ ZANKER (n. 2) 336.

${ }^{84}$ ZANKER (n. 2) 336-337.
} 
phy as wholly consistent with the official ideology of the saeculum aureum. It is further confirmation that we must certainly rid ourselves of the axiom that an opposition Dionysus/Apollo was at the heart of Augustan art and ideology, and that the longstanding rivalry between Octavian and Antony would inevitably produce an opposition between Augustus and Dionysus.

We are further urged to abandon this schematisation when we turn to the decorative programme of the Casa della Farnesina. The ruins of this villa were discovered along the river Tiber in an area where in the late Republic and first Empire luxurious mansions with their horti ${ }^{85}$ were many. According to the prevailing interpretation, the villa was commissioned by Agrippa. ${ }^{86}$ Consistently with this hypothesis, Zanker underlines how the decorative programme of the "Casa della Farnesina" is an apt example of Imperial imagery in the private sphere. ${ }^{87}$ He suggests that the celebration of the Augustan saeculum aureum is expressed, in particular, by the stucco panels on the vaulted ceiling of the so-called "Cubiculum B", which represents scenes of devotion within bucolic and idealized landscapes. ${ }^{88}$

What is particularly remarkable here is how many of these devotional scenes convey a deeply Dionysiac atmosphere. The Dionysiac features are expressed, first of all, by the panels at the corner of the vault, which are, unfortunately, very lacunous. Here the references to the Dionysiac rituals are highly detailed. The generic sacred landscapes are replaced with scenes which, although including some mythical characters, depict actions and gestures ascribable to actually performed rituals. One of these panels, very lacunous at present, portrayed a small group of women involved in a ritual which implied the presence of a liknon, one of the most prominent emblems of Dionysus. An additional panel displays a Papposilenus, a kneeling woman stroking a panther and a second woman with a semi-supine young man: a probable allusion to a ritual. A further panel illustrates the initiation of a veiled child bearing a thyrsus, with

${ }^{85}$ On the discovery see LANCIANI, R.: Notizie degli Scavi 1879, 33; 1880, 127-138; 1895, 42-43 and MAU, A.: Annali dell'Istituto 1882, 301-314; 1884, 307-32, 1885, 302-318. The inventory of the decorations is in Bragantini, I. - De Vos, M.: Museo Nazionale Romano. Le pitture. II 1. Roma 1982, $17-21$.

${ }^{86}$ Beyen was the first who considered Agrippa the client of the "Casa della Farnesina": BEYEN, H.: Les Domini de la Villa de la Farnesine. In Studia varia Carolo Guilielmo Vollgraff a discipulis oblata. Amsterdam 1948, 2-21. In particular, he dates the building to $25 \mathrm{BC}$, and the decorations to a later period, after $21 \mathrm{BC}$. The hypothesis that the clients of the decorations were Agrippa and Giulia is followed by most scholars, who have pointed out further elements which confirm the consistence of these decorations with the Augustan ideology: SCHEFOLD, K.: La peinture pompéienne. Essai sur l'évolution de sa signification. Bruxelles 1972; ANDREAE, B.: L'art de l'ancienne Rome. Paris 1973; RoDDAZ, J.-M.: Marcus Agrippa. Roma 1984; DURET, L.: Néron-Phaéton ou la témérité sublime. In REL 66 (1988) 139-155; BERGMANN, B.: Greek Masterpieces and Roman Recreative Fictions. HSCP 97 (1995) 79-120; KRAUSE, C.: Hemizyklien im frühkaiserzeitlichen Villenbau. RM 107 (2000) 37-78; FORESTA, S.: La villa della Farnesina: un punto di vista privato. Ricezione e rielaborazione di modelli ellenistici a Roma. Incidenza dell'antico 2 (2004) 113-135. On these themes see SCAPINI (n. 41) 272-295, where I report the status quaestionis and the bibliography.

${ }^{87}$ A similar idea is expressed by FORESTA (n. 86), who believes that the decorative programme is aimed at expressing the pietas of the client who thus claimed his adherence to the renewed moral values of the Principate.

${ }^{88}$ ZANKER (n. 2) 290. 
a cista mystica on the right. Another panel also depicts a scene of initiation this time involving two Satyrs (one is pouring some vine and bears a thyrsus), a naked child with thyrsus and timbrel and a woman with a patera.

The vault of "Cubiculum D" offers additional ritual scenes characterised by a Dionysiac atmosphere, along with references to other gods, such as Zeus and Apollo. One panel illustrates a sacred landscape including a Priapic herm; ${ }^{89}$ another shows a group of Maenads bearing offerings to another Priapic herm; the third depicts a young flute player, a Maenad performing a ritual, a drunken Papposilenus and a veiled woman. The fragments of two central little panels remain: one probably represented a bearded Dionysus and the other Ariadne. ${ }^{90}$

Apart from the ceiling stucco reliefs, in the "Cubicula B and D" Dionysus and Dionysiac themes appear on the wall frescoes, as well. In particular, on the left wall of "Cubiculum D" a panel depicted a Maenad with an opened cista. ${ }^{91}$ The more renowned wall frescoes of "Cubiculum B" also include Dionysus, in the well-known scene depicting breastfeeding Leukothea which flanks a panel representing Venus, Eros and a woman (Peithō?).

Irene Bragantini and Mariette De Vos focus on the sophisticated composition on the walls of this room, which echoes thematic schemes of Classical and Hellenistic Greece, and they suggest that, in this particular case, the clients must have been more interested in the decorative effect than in the contents of the scenes themselves. ${ }^{92}$ And yet the Dionysiac atmosphere evoked by characters on the walls of both "Cubicula B and D" is undoubtedly emphasized by the ceiling stuccoes, where, as we have seen, the Dionysiac scenes appear to be more than a mere decorative filling. Allusions to the Dionysiac universe also appear in the "Ambulacrum G": here satyr masks appear along with a representation of a sacred landscape including a handful of characters involved in an orgiastic dance.

Additional panels of the Casa della Farnesina - this time more clearly related to rituals actually performed - encourage the impression that the presence of Dionysus and of Dionysiac themes in this context was much more than a mere decorative phenomenon and, rather, an expression of a specific Dionysiac religiosity. These panels - fifteen little pinakes - were found in the so-called "Criptoporticus A". 93 Eleven of them (inventory numbers 1210, 1213, 1203, 1212, 1204, 1206, 1207, 1197, 1198, 1199,1211 ) have been dated precisely to the first years of the Augustan Age, whereas the others (inventory numbers $1195,1196,1208,1209$ ) seem to be the product of a later restoration. Certain ones are specifically connected to Dionysus or Dionysiac

${ }^{89}$ BRAGANTINI-DE VOS (n. 85) Inv. 1037, tav. 111.

${ }^{90}$ BRAGANTINI-DE VOS (n. 85) 193-194.

${ }^{91}$ BRAGANTINI-De VOS (n. 85) 191.

${ }^{92}$ BRAgantini-De Vos (n. 85) 128-129. Contra WYLER, S.: Dionysus Domesticus. Les motifs dionysiaques dans les maisons pompéiennes et romaines (II ${ }^{\mathrm{e}} \mathrm{S}$. AV. $-\mathrm{I}^{\mathrm{er}} \mathrm{S}$. AP. J. C.). MEFRA 116 (2004) 2, 938; and WYLER, S.: Roman Replications of Greek Art at the Villa della Farnesina. Art History 29 (2006) 213-232. She believes that the presence of Dionysus in this Cubiculum, emphasized by a few Putti provided with thyrsi and a few Sileni which appear within the architectonical frame including the big panels, expresses a specific ideological and religious programme by the clients.

${ }^{93}$ BRAGANTINI-DE VOS (n. 85) 82-119. 
rituals and are iconographically comparable to previous representations deeply rooted in Hellenistic visual imagery, such as the fresco of the "Villa dei Misteri". In particular, 1213 represents a scene of the childhood of the god; ${ }^{94} 1204$ shows the semi-supine god flanked by members of his thiasos; inv. 1206 depicts a sacrifice performed in front of a Priapic herm; ${ }^{95} 1195$ illustrates a man bearing a liknon.

How are we to interpret such a redundant presence of Dionysus in these iconographies? We have seen how Zanker and, more recently Foresta, have interpreted the religious atmosphere expressed by these pictures as a claim of adherence to Augustan religious pietas and the conception of the saeculum aureum. Moreover, on the basis of the prevailing presence of Dionysus and the overwhelming allusions to specific Dionysiac practices which appear to mirror genuine rituals, I am convinced that the decorative programme of the Casa della Farnesina may well be considered deliberately and expressly Dionysiac and therefore something more than a generic claim of religiosity. This concept has been recently proposed by Stéphanie Wyler, who, in fact, speaks of a specific "programme Dionysiaque". 96 Nevertheless, we have seen that this scholar, by following the common interpretative path of a rehabilitation of the god according to the new ideology, is swayed to some extent by the timeworn scholarly axiom of the potential difficulty and paradox within the acculturation of Dionysus into Augustan ideology after Actium. ${ }^{97}$

But actually, would a specific worship of Dionysus be necessarily in contrast with the adherence to Augustan ideology? To what extent was the integration of

${ }^{94}$ Rizzo linked this scene to the central group of the Dionysiac fresco of the Villa dei Misteri (RIzzO, G. E.: Dionysos Mystes. Contributi esegetici alla rappresentazione dei misteri orfici [Memorie dell'Accademia Arch. Di Napoli 75]. Napoli 1914).

${ }^{95}$ RizzO (n. 94) 68-69, linked this scene, too, to the Dionysiac frieze of the "Villa dei Misteri". He has connected to the frieze of the "Villa dei Misteri" the pinax inv. 1197 (BRAGANTINI-DE VOS [n. 85] 88-89) as well, which represents three characters (one of them is winged) whom Bragantini and De Vos consider involved in an instruction on sacred liturgy. Moreover, according to Rizzo, a further theme shared by the Casa della Farnesina and the Villa dei Misteri is the kneeling woman close to another woman, depicted on the right of one of the panels of Cubiculum B: he links in fact this scene to the famous kneeling woman in the frieze of the Villa dei Misteri. After Rizzo many scholars have proposed parallelisms between the iconographies of the Casa della Farnesina and of the Villa dei Misteri: see, for instance, SAURON, G.: La grande fresque de la Villa des Mystères à Pompei. Paris 1998.

${ }^{96}$ WYLER: Dionysus Domesticus (n. 92) and WYLER: Le dionysisme (n. 41).

${ }^{97}$ She believes that the key of such a presumed rehabilitation, such a "rehabilitative acculturation" and creation of a Dionysism specifically Augustan - is a strict association between Dionysus and Venus whose picture, as we have seen, flanks that of Dionysus and Leukothea in the Cubiculum B: WYLER: Le dionysisme (n. 41): "Une association essentielle avec Vénus, et une relation complexe mais insistante avec l'Égypte hellénistique, de laquelle d'image du dieu, si compromise par les vies inimitables d'Antoine et de Cléopâtre, est détournée au profit d'un visage beaucoup plus classique, quasiment au sens attique du terme. (...) Le rôle nouveau dévolu à Venus modifie sensiblement le sens du programme décoratif, cautionnant en quelque sorte celui de Bacchus, tandis que le dieu conserve les connotations dont il est investi - en tant que modèle alexandrin de souveraineté et figure d'une culture mystico-philosophique que reflètent vraisemblablement les stucs" (pp. 70-71). "Si Vénus est publiquement la mère d'Énée et protectrice se sa lignée, elle l'est aussi d'Éros (...). Dans cette optique, qui réconcilie la moralité de la nouvelle politique, autour du mariage et de la natalité des grandes familles (...), Dionysos se trouve à double titre intégré dans la logique augustéenne : en tant que porteur d'un message de souveraineté hellénistique, en tant qu'associé de Vénus dans ses manifestations érotiques (...)” (p. 75). 
Dionysus perceived as paradoxical by the people to whom such iconographies were addressed? Is it not possible that such a paradox is, in fact, located nowhere other than in our own minds? Indeed, by adopting an inductive perspective, the presence of Dionysiac themes in the Casa della Farnesina - which do not differ iconographically from the traditional Hellenistic schemes - simply indicates that Augustan ideology inherited, without any apparent difficulties, precise traditional Dionysiac themes, including motifs strictly related to the Hellenistic Dionysiac mystery cults. More precisely, by no means does it appear that there was an aut aut between a full adherence to Augustus's ideology and a specific sympathy for Dionysus.

\section{CONCLUSION}

Indubitably, my considerations and the testimonies proposed herein - which essentially belong to the sphere of art and literature - cannot suffice to clarify the role of Dionysus in Augustan religious policy. Nevertheless, the evidence demonstrates that not only did a prestigious Augustan Dionysus exist, but that there were also numerous "Augustan Dionysi", 98 each one expressing both a particular meaning as well as a more or less traditional role, and that these were often mingled together, namely: the promoter of viticulture and civilisation, the patron of banquets, the symbol of fecundity of nature, the prototype of benefactor of Mankind.

The Hellenistic Dionysus, the royal Hellenistic god, the archetype of the conqueror of the East, strictly linked to the myth of Alexander, whom Antony chose as a model, also belonged to the Augustan imagery: this specific Dionysus was even a possible term of comparison for the Princeps. Since the integration of all these symbolisms occurred both before and after Actium, we therefore have proof that the polarised interpretation which has been systematically applied to Dionysus under Augustus - and that interprets the presence of the god in the Augustan world as a paradox to somehow justify - is in point of fact totally arbitrary. What is more, the triumph of Dionysus, and the overwhelming presence of the god in the art and literature of Rome before and after Actium and in the Augustan Rome, suggests that such a presumed paradox is nothing more than a modern prejudicial perception.

Marianna Scapini

University of Verona

marianna.scapini@gmail.com

${ }^{98}$ See Cicero's Dionysos multos (Cic. Nat. Deor. III 23). 